\title{
PENGARUH GAYA KEPEMIMPINAN TERHADAP KINERJA KARYAWAN PADA SMA ISLAM AL - AZHAR BUMI SERPONG DAMAI - KOTA TANGERANG SELATAN
}

\author{
Raden Yeti Sumiaty
}

Staf Pengajar Fakultas Ekonomi Universitas Pamulang email: dosen02250@unpam.ac.id atau rd.yetisumiaty@gmail.com

\begin{abstract}
ABSTRAK
Tujuan kajian ini adalah untuk menentukan gaya kepimpinan Sekolah Tinggi Islam Al-Azhar Bumi Serpong Damai-Selatan Tangerang, untuk menentukan prestasi pekerja di Sekolah Tinggi Islam Al-Azhar Serpong Damai-Selatan Tangerang untuk mengetahui sejauh mana pengaruh gaya kepimpinan terhadap prestasi pekerja di Sekolah Tinggi Islam Al-Azhar Serpong Damai, Bandar Tangerang Selatan. Kaedah dalam kajian ini adalah menggunakan regresi linier berganda, dengan tahap ujian asumsi klasik (normality data, multicollinearity dan heteroscedasticity), koefisien penentuan, analisis koefisien regresi berganda linear dan ujian signifikan $(t$ dan $F$ ). Data yang digunakan adalah data primer dengan menyebarkan soal selidik kepada responden, iaitu pekerja di Sekolah Tinggi Islam Al-Azhar Serpong Damai - Tangerang Selatan, berjumlah 100 orang pekerja. Keputusan menunjukkan bahawa gaya kepimpinan yang diterima pakai oleh para pemimpin Sekolah Al-Azhar adalah kuat. Ini dapat dilihat dari responden atau tanggapan responden yang setuju dan setuju dengan soalan yang mencerminkan pelbagai jenis gaya kepimpinan, dengan magnitud $72.46 \%(\mathrm{SS}+\mathrm{S}=22.46 \%+50 \%=72,46 \%$ ), baki $27.54 \%$ disebabkan oleh faktor lain. Dari hasil pengiraan di atas dapat disimpulkan bahawa prestasi pekerja di Sekolah Al-Azhar adalah kuat. Ini dapat dilihat dari responden atau tanggapan responden yang menyatakan dengan tegas setuju dan bersetuju dengan soalan-soalan yang mencerminkan prestasi pekerja, manakala jumlah $75.22 \%(\mathrm{SS} ; 25.65 \%+\mathrm{S} ; 49.57 \%=75,22 \%)$, baki $24.78 \%$ disebabkan oleh faktor lain. Pengaruh gaya kepimpinan terhadap prestasi pekerja di Sekolah Al-Azhar dapat dilihat dari magnitud nila1 rxy 0.68 , yang menunjukkan kesan pemboleh ubah X pada pemboleh ubah $\mathrm{Y}$ adalah kuat. Ujian penting dengan ujian $t$ ialah $t$ hitung $>t$ jadual atau $6.18>1.68$. Ini bermakna keputusan pengiraan ujian serentak menunjukkan terdapat pengaruh gaya kepimpinan yang signifikan terhadap prestasi pekerja Sekolah Tinggi lslam Al-Azhar.
\end{abstract}

Kata kunci: gaya kepemimpinan, kinerja karyawan.

\section{ABSTRACT}

The purpose of this study was to determine the leadership style of the Al-Azhar Bumi Serpong Damai Islamic High School-South Tangerang City, to determine the performance of employees at the Al-Azhar Islamic High School Serpong Damai-South Tangerang City, to find out how much influence the leadership style has on performance employee at Al-Azhar Islamic High School Serpong Damai, South Tangerang City. The method in this research is to use.multiple linear regression, with the classical assumption test stages (data normality, multicollinearity and heteroscedasticity), the coefficient of determination, multiple linear regression coefficient analysis and significant test $(t$ and $F)$. The data used are primary data by distributing questionnaires to respondents, namely employees at the Al-Azhar Islamic High School Serpong Damai - South Tangerang City, totaling 100 employees. The results showed that the leadership style adopted by the leaders of the Al-Azhar School was strong. This can be seen from the respondents or responses of respondents who agree and strongly agree with questions that reflect various
types of leadership styles, as for the magnitude of $72.46 \%$ remaining $27.54 \%$ is caused by other factors. From the results of the above calculations it can be concluded that the performance of employees at Al-Azhar School is strong. This can be seen from the respondents or the responses of respondents who stated strongly agree and agree to the questions in which reflect the performance of employees, while the amount of $75.22 \%$ (SS: $25.65 \%+5 ; 49.57 \%=75$, $22 \%$ ), the remaining $24.78 \%$ is caused by other factors. The influence of leadership style on employee performance in the Al-Azhar School can be seen from the magnitude of the rxy value of 0.68, which indicates the effect of the $X$ variable on the $Y$ variable is strong. Significance test with the $t$ test is $t$ indicates the effect of the $X$ variable on the Y variable is strong. Significance test with the $t$ test is $t$
count $>$ t table or $6.18>1.68$. This means that the results of the calculation of the simultaneous test show that there is a significant influence of leadership style on the performance of Al-Azhar Islamic High School employees.

Keywords: leadership style, employee performance.

\section{PENDAhuluaN}

\section{A. Lattar Belakang}

Dalam era yang semakin maju seperti ini banyak perubahan telah berlaku. Salah satunya adalah perubahan ekonomi pesat negara, tetapi perubahan ini kadang-kadang membuat kemajuan atau kemunduran untuk rakyat sendiri. Pada 


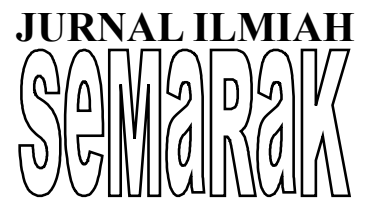

masa ini orang kadang-kadang mengalami kesukaran dalam menangani ekonomi mereka. Satu contoh ialah rakyat Indonesia dalam menghadapi ekonomi Asean 2015 yang telah dirancang oleh para pemimpin ASEAN .

Indonesia sendiri sebenarnya mempunyai banyak peluang untuk bersaing dalam Komuniti Ekonomi Asean (AEC). Indonesia adalah negara pertanian. Tanah Indonesia sesuai untuk menanam rempah-rempah dan tanaman lain yang diperlukan oleh banyak negara di dunia .

Dengan perkara seperti itu, bagaimanakah kita menggunakan MEA itu sendiri? Di negara kita terdapat banyak sektor yang boleh digunakan. Dan juga dalam sektor perikanan, kita tahu sendiri bahawa lebih dari 50\% wilayah Indonesia adalah air. Kemudian kita juga memiliki sumber daya alam yang berlimpah, seperti Lapindo lumpur, dari tahun 2004 sampai sekarang lumpur masih kosong. Sekiranya ia digunakan dengan baik, ia dapat membantu ekonomi Indonesia menjadi lebih maju .

Oleh itu, untuk menghadapi AEC mesti melaksanakan pembangunan di semua sektor. Sumber manusia mesti diperbaiki, jadi kami boleh memproses produk semulajadi yang ada .

Dalam era globalisasi isu kepimpinan selalu memberikan kesan yang menarik. Sebuah organisasi atau syarikat akan berjaya atau bahkan gagal, sebahagian besarnya ditentukan oleh kepimpinan.

Dalam mengetuai sebuah syarikat, tidak semua pemimpin mempunyai gaya kepimpinan yang sama. Setiap pemimpin mesti dapat meletakkan gaya kepimpinannya mengikut keadaan dan keadaan syarikat, supaya pekerja dapat bekerjasama dalam mencapai matlamat syarikat .

Menurut Heidjrachman dan Suad Hasan (2002:65), Gaya Kepemimpinan adalah pola oleh orang lain kerana pemimpin yang berjaya adalah seorang pemimpin yang dapat menyesuaikan gayanya agar sesuai dengan keadaan tertentu . Menurut Sugiyono (2003:132), pada saat penjelasan tugas-tugas kelompok maka ia harus bergaya direktif, pada saat meenunjukan haal-haal "yang boleh menarik ahli-ahlinya maka dia perlu gaya perundingan, untuk merumuskan matlamat" kumpulan yang dia menyertikan gaya sedangkan pada saat bawahan telah mampu dan berpengalaman dalam menghadapi suatu tugas maka ia bergaya delegatif.

Implikasi kepeemimpinan terhadap organisasi adalah seberapa jauh pemimpin dapat menstransformasi pendekatanpendekatan teori kepemimpinan sebagai acuan dalam melakukan tugasnya. Sehingga para pemimpin memiliki 


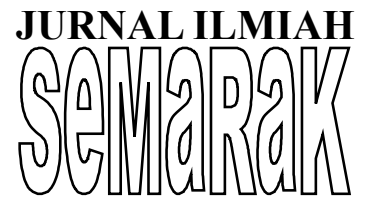

kemampuan mempengaruhi dan dapat memotivasi kepada bawahan yang akan berpengaruh terhadap peningkatan kinerja.

Menurut Dessler Seperti yang di kutip Mangkuprawira, S (2007:153) Kinerja merupakan prosedur yang meliputi:

1. Penetapan Standar Kinerja

2. Penilaian kinerja actual pegawai dalam hubungan dengan standar-standar ini.

Selanjutnya Handoko (2001:143) menyatakan bahwa kinerja (performance appraisal) adalah proses melalui mana organisasi-organisasi mengevaluasi atau menilai prestasi kerja karyawan dimana dalaam kegiatan ini dapat memperbaiaki keputusan-keputusan personalia dan memberikan umpan balik kepada para karyawan tentang pelaksanaan kerja mereka.

Penulis menggambarkan pula bahwa kepemimpinan adalah usaha mempengaruhi orang lain supaya dapat menurut kepada sasaran yang diinginkan oleh pimpinan, dan seorang pimpinan dalam memimpin syarikat akan menggunakan kaedah kepimpinan yang sesuai, mengikut situasi dengan matlamat syarikat .

Kepemimpinan mengambil peranan yang sangat penting dalam sebuah kelompok atau organisasi dapat dikatakan atau menentukan, dalam usaha pencapaian tujuan yang ditetapkan sebelumnya.
Pemimpin membutuhkan sekelompok yang lain dikenali sebagai orang bawahan yang dipindahkan, diarahkan, dipupuk sedemikian rupa sehingga bawahan berpartisipasi dalam memberi peranan mereka dengan cara bekerja secara efektif, efisien, ekonomis dan produktif sebagai bentuk pengabdian kepada organisasi. Gaya kepemimpinan yang sesuai dengan keinginan perusahaan dan keinginan bawahan akan mendorong peningkatan kerja bagi karyawan. Karena kinerja yang baik akan dapat menunjang pencapaian sasaran dan tujuan perusahaan, namun seringkali didapat bahwa pimpinan gagal untuk mempengaruhi orang-orang nya untuk mendapat meningkatkan kinerjanya. Permasalahan yang timbul adalah banyak pimpinan mengalami kegagalan untuk mempengaruhi bawahannya dalam meningkatkan kinerjanya.

Dri uraian tersebut di atas, maka penulis tertarik untuk memilih judul penelitian mengenai "Pengaruh Gaya Kepemimpinan Terhadap Kinerja Karyawan Pada SMA Islam Al-Azhar Bumi Serpong Damai-Kota Tangerang Selatan".

\section{B. Perumusan Masalah}

Berdasarkan pengenalan dan pembatasan masalah di atas, penulis merumusan masalah sebagai berikut : 


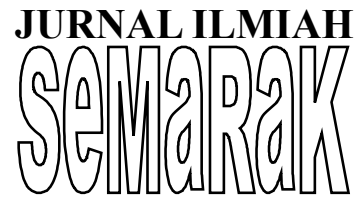

1. Bagaimana gaya kepemimpinan pada Sekolah Islam Al-Azhar Bumi Serpong Damai-Kota Tangerang Selatan ?

2. Bagaimana kinerja karyawan pada SM A Isslam All-Azzhar Buumi Serponng Damai-Kota Tangerang Selatan?

3. Seberapa besar pengaruh gaya kepemimpinan terhadap kinerja karyawan pada SMA Islam Al-Azhar Bumi Serpong Damai-Kota Tangerang Selatan?

\section{Tujuan Penelitian}

Penelitian ini bertujuan untuk menguji dan menganalisis proses kegiatan yang dilakukan di PT. Inkabiz Indonesia, yaitu:

1. Untuk mengetahui gaya kepemimpinan pada SM A Isl am Al-A zhar B umi Serrpong Daamai-Koota Taangerang Selataan.

2. Untuk mengetahui kinerja karyawan pada SMA Islam Al-Azhar Bumi Serpong Damai-Kota Tangerang Selatan.

3. Untuk mengetahui seberapa besar pengaruh gaya kepemimpinan terhadap kinnerja karryawan pda SMA Islam AllAzzhar Buumi Serponng Damai-Kota Tagerang Sellatan.

\section{TINJAUAN PUSTAKA}

\section{A. Manajemen}

Manajemen berasal dari kata to manage yang artinya mengatur. Sedangkan definisi manajemen adalah ilmu dan seni mengatur proses pemanfaatan sumber daya manusia dan sumber lain dengan berkesan dan cekap untuk mencapai matlamat tertentu .

Menurut Malayu Hasibuan (2001:2) menyatakan bahwa "Manajemen adalah ilmu dan seni mengatur proses pemanfaatan sumber daya manusia dan sumber lainnya secara efektif dan efisien untuk mencapai tujuan.

Sedangkan menurut M. Manulang (2001:5) berpendapat bahwa " Manajemen adalah seni dan ilmu perencanaan, organisasian, penyusunan, pengarahan dan pengawasan dari summber daaya manuusia untk mencaapai tjuan yng tlah ditetapkan terlebih dahulu ". Bagaimana usaha agar manajemen itu sesuai dengan konsep fleksibel dan didukung oleh nilainilai yang baik? Hal ini sebagian besar ditentukan oleh dedikasi, keahlian dan otoritas para manajer. Dedikasi menunjukan pengabdian mereka kepada organisasi, keahlian yang diperoleh melalui pendidikan merupakan bekal dalam bekerja disamping pembawaan dan otoritas mereka bertindak.

McHugh (Sule, 2010:6) menyatakan bahwa "Manajemen adalah suatu proses yaang dillakukan unntuk mewuujudkan tujuaan organisasi mellalui ranngkaian kegiiatan berupa perencanaan, pengorganisasian, pengarahan, dan pengendalian orang-oraang serta sumbeer 


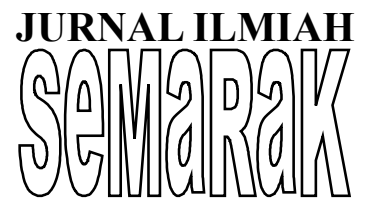

dayya orrganisasi lainnya". Manajemen merupakan seni atau prses dalam menyelesaikan kegiatan organisasi. Manajemen sebagai seni mengandung arti keterampilan pribadi, dan manajemen sebagai proses merupakan cara sistematis utuk melakukan pekerjaan.

Panggabean (2004:13) menyatakan bahwa "Manajemen merupakan sebuah proses yang terdiri atas fungsi-fungsi perencanaan, pengorganisasian, pimpinan, dan pengendalian kegiatan SDM untuk mencaapai tuujuan yng dittapkan secara efisien". Mnajemen merpakan suatuu proses perencanaan, pelaksanaan, daan pengendalian, karena apa yang direncanakan harus dilaksanakan dan dalam pelaksanaannya paling tidak ada kegiatan untuk menyesuaikan rencana dengan struktur organisasi dan gaya kepemimpinan, dan selanjutnya apa yang dilaksanakan perlu dikendalikan untuk menjamin agar pelaksanaan sesuai dengan rencana yang telah dirumuskan.

Menurut Simamora

(2006:4) menyatakan "Manajemen merupakan proses pendayagunaan bahan baku dan summber daaya maanusia unntuk menccapai tujuan yang ditetapkan”. Proses ini melibatkan orgaanisasi, arahan, koordinasi daan penilaian oraang untuk mencapai matlamat ini. Intipati pengurusan adalah aktiviti bekerja meelalui orrang lain unntuk meencapai pelbagai hasil. Melalui pengurusan proses mengintegrasikan pelbagai sumber dan tugas dilaksanakan untuk mencapai matlamat

\section{B. Mnajemen Smber Daaya Manuusia}

Manajemen Sumber Daya Manusia adalah proses pengelolaan manusia, melalui perencanaan, rekrutmen, seleksi, pelatihan, pengembangan, pemberian kompensasi, karier, keselamatan dan kesehatan serta menjaga hubungan industrial sampai pemutusan hubungan kerja guna mencapai tujuan perusahaan dan peningkatan kesejahteraan stakeholder. Pengertian manajemen sumber daya manusia dari beberapa ahli MSDM: Noe menyebutkan Human Resources Management refers to Policies, practices and systems that influenza employees' behavior, attitudes, and performance (manajemen sumber daya manusia merupakan bagaiman mempengaruhi perilaku, sikap dan kinerja melalui kebijakan dan sistem yang dimiliki oleh perusahaan. Menurut Dessler Human Resources Management is the process of acquiring, training, appraising and compensating employees, and attending their labor relations, health and safety, and fairness concern (manajemen sumber daya manusia merupakan proses menangani karyawan pelatihan penilaian, kompensasi, hubungan kerja kesehatan 


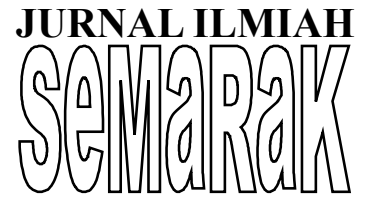

dan keamanan secara adil terhadap fungsifungsi MSDM (Kasmir, 2015:6).

Menguruskan sumber manusia mesti dilakukan dengan betul mengikut peraturan manusia atau sifatnya. Jika pada masa lalu atau pekerja dianggap sebagai mesin yang dapat dilakukan secara sewenang-wenang untuk mencapai matlamat syarikat. Manusia dianggap sebagai budak yang boleh ditadbir mengikut kehendak. Tetapi sekarang, selaras dengan perkembangannya, orang semakin dipertimbangkan, walaupun kini ia menjadi aset paling penting untuk dipertimbangkan (Kasmir, 2016:5).

Sutriisno (2016:3) mengatakan bahwa sumbeer mannusia adalah sattu-sattunya summber yaang mempunyai perrasaan perasaan, keiinginan, kemahiran, pengettahuan, doronngan, kuasa daan kerja (nisbah, raasa daan niat). Kesemua sumber daya manusia yang berpotensi ini mempengaruhi usaha organisasi dalam mencapai matlamat.

Menurut Bangun (2012: 5) pemahaman tentang pengurusan sumber manusia adalah satu aktiviti yang merangkumi perancangan, penganjuran, penyediaan personel, menggerakkan dan mengawasi fungsi operasional untuk mencapai matlamat syarikat .

Berdasarkan pemahaman di atas, dapat disimpulkan bahwa pemahaman tentang Pengurusan Sumber Manusia adalah semua kegiatan dengan menggerakkan sumber daya manusia yang ada untuk mencapai tujuan perusahaan .

\section{Gaya Kepemimpinan (X)}

Kepimpinan tidak lagi berdasarkan bakat dan pengalaman sahaja, pada masa ini pemimpin bergerak ramai orang untuk melakukan kerja sama terima kasih kepada kepimpinan yang diperoleh melalui latihan dan pendidikan.

Kepemimpinan atau Leadership termasuk kelompok ilmu terapan atau applied sciences dari ilmu-ilmu sosial, sebab prinsip-prinsip dan rumusanrumusan yang bermanfaat dalam meningkatkan kesejahteraan manusia dan berinterksi deengan lingkungan serta dapat mempenngaruhi pola fikir orang lain menjadi lebih baik. Pemimpin merupakan faktor penentu dalam sukses atau gagalnya suatu organisasi atau instansi, baik di dunia bisnis maupun di dunia pendidikan, kesehatan, perusahaan, religi, sosial, negara dan lain-lain. Kualitas pemimpin menentukan keberhasilan lembaga atau organisasinya. Pemimpin yang sukses adalah sosok pemipmin yang mampu mengelola organisasi, mampu mempengaruhi secara konstruktif orang dan menunjukkan jalan perilaku yang benar yang harus dikerjakan bersamasama.

Kartono (2005:153) mengatakan kepemimpinan adalah kemampuan untuk memberikan pengaruh yang konstruktif kepaada orrang lain unntuk mellakukan 


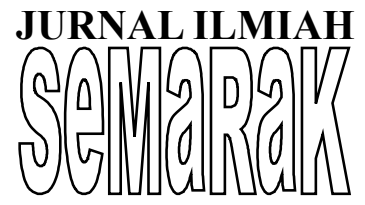

suattu ussaha koperatif mnecapai tujuan yang suddah dirncanakan. Veitzhal Rivai (2004:65) menyatakan kepemimpinan adalah peranan dan juga suatu proses untuk mempengaruhi orang lain.

Etzioni (Sarojo, 2008:12) menyatakan "Kepemimpinan ialah kekuatan yang berdasarkan kepada karekteristik perorangan yang biasanya bersifat normatif", Kepemimpinan adalah proses mempengaruhi kegiatan-kegiatan kelompok yang di organisasi untuk mencappai tuujuan yanng tellah ditetappkan. Kepemiimpinan addalah sebagai pengaruh seni atau proses mempengaruhi orang lain sehingga mereka akan berusaha mencapai tujuan kelompok dengan kemampuan antusias.

Menurut Purwanto (2008:26) bahwa "Kepemimpinan adalah sekumpulan dari serangkaian kemampuan dan sifat-sifat kepribadian, termasuk didalamnya kewibawaan, untuk dijadikan sebagai sarana dalam rangka meyakinkan yang dipimpinnya agar mau dan dapat melaksanakan tugas-tugas yang dibebankan kepadanya dengan rela, penuh semangat, ada kegembiraan bathin, serta merasa tidak terpaksa". Kepemimpinan, yaitu: suatu proses mempengaruhi kegiatan individu atau kelompok dalam usaha mencapai tujuan dalam situasi tertentu.
Definisi kepemimpinan tersebut diatas dapat disimpulkan bahwa kepemimpinan memiliki tugas penting, antara lain: (1) kepemimpinan menyangkut orang laian, yaitu bawahan atau pengikut, (2) kepemimpinan menyangkut suatu pembagian kekuasaan diantara pimpinan dengan anggota kelompok, dan (3) pimpinan dapat juga menggunakan pengaruh selain dapat memberikan pengarahan. Dari hal-hal penting diatas maka dapat disintesiskan bahwa kepemimpinan adalah kemampuan untuk memberikan pengaruh kepada orang lain, baik secara individu maupunkelompok, agar bekerja sama dengan sadar dan antusias dalam rangka membantu mencapai tujuan yang ditetapkan.

Menurut Robbins

(2003:41) menyatakan "Tentang teori kepemimpinan telah mengindentifikasikan ada enam karakter, yaitu : 1) ambisi dan energi, 2) hasrat untuk memimpin, 3) kejujuran dan integrasi, 4) percaya diri, 5) kecerdasan, 6) pengetahuan yang relevan dengan pekerjaan".

Menurut Luthans (Wirawan, 2003:80) menyatakan " Gaya Kepemimpinan adalah cara pemimpin mempengaruhi para pengikutnya dan gaya kepemimpinan dipengaruhi oleh budaya". Menurut Overton (Syafaruddin, 2010:74) bahwa "Perilaku kepentingan terfokus terhadap 


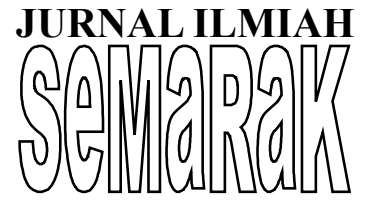

fungsi kepemimpinan dan gaya kepemimpinan. Seorang pemimpin menjalankan kepemimpinannya dengan berbagai perilaku yang didorong untuk mencapai tujuan sesuai dengan tugas dan tanggung jawabnya sebagai pimpinan organisasi tertentu".

Gaya kepemimpinan pada dasarnya dapat ditinjau dari berbagai sudut pandangan. Jika dilihat dari sudut perilaku pemimpin menurut Schmit (Sutrisno, 2009:241-242) menyatakan bahwa "Sifat ekstrim dari sifat otokratis sampai demokratis dipengaruhi oleh intensitas penggunaan kekuasaan oleh pemimpin dan penggunaan kebebasan oleh pengikut. Kombinasi dari kedua faktor inilah yang menentukan pada tingkat mana seorang pemimpin mempraktikkan perilaku kepemimpinan". Gaya kepemimpinan dapat dimiliki oleh seorang pemimpin secara ideal, bilamana pemimpin memiliki kemampuan memimpin dengan memiliki kepribadian yang baik dan pengetahuan berwawasan luas.

Syafaruddin

menyimpulkan bahwa "Gaya kepemimpinan ialah suatu pola perilaku yang konstiten ditampilkan seseorang dan yang diketahui oleh pihak lain ketika dia berusaha mempengaruhi kegiatan-kegiatan orang lain. Gaya kepemimpinan juga diarahkan sebagai pendekatan yang dilakukan oleh pemimpin dalam mempengaruhi orang lain untuk melaksanakan kegiatannya bersama atau dengan anggota-anggotanya”. Jadi gaya kepemimpinan timbul atas kegiatan antara pimpinan mempengaruhi bawahannya yang berhubungan dengan sejumlah faktor yang komplek sifatnya, yaitu : ada pemimpin, yang dipimpin, organisasi yang bersangkutan, dan nilai-nilai situasi yang berkaitan dengan kegiatannya.

Menurut Sutrisno (2009:242-243) membagi "Gaya kepemimpinan antara lain : (1) gaya persuasif; (2) gaya refresif; (3) gaya partisipatif; (4) gaya inovatif; (5) gaya investigatif; (6) gaya inspektif; (7) gaya motivatif; (8) gaya naratif; (9) gaya edukatif; dan (10) gaya retrogresif". Seorang pemimpin dapat berhasil dalam organisasinya dengan menerapkan lebih dari satu macam gaya, untuk itu pemimpin yang berhasil harus menerapkan gaya kepemimpinan yang berbeda-beda sesuai dengan situasi yang berbeda pula.

Kemampuan yang perlu diwujudkan seorang pemimpin dapat dianalisis dari kepribadian, pengetahuan terhadap pegawai, visi dan

misi instansinya, kemampuan mengambil keputusan, dan kemampuan berkomunikasi. Menurut kartono (2033:29) bahwa "Pemimpin itu mempunyai sifat, kebiasaan, temperamen, watak dan kepribadian sendiri yang khas, sehingga tingkah laku dan gayanyalah 


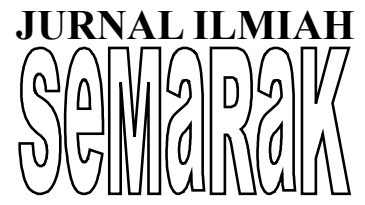

yang membedakan dirinya dari orang lain. Gaya atau style hidupnya ini dapat mewarnai perilaku dan tipe kepemimpinannya".

Menurut Wahjosumidjo (2008:25-29) bahwa "Teori kepemimpinan ada empat faktor meliputi dimensi-dimensi : struktural, fasilitatif, suportif, dan partisipatif”. Kepemimpinan struktural dengan indikasi : (a) cepat mengambil tindakan dalam keputusan yang mendesak; (b) melaksanakan pendelegasian yang jelas dan menentukan kepada para anggota staf; (c) menekankan kepada hasil dan tujuan organisasi; (d) mengembangkan suatu pandangan organisasi yang kohesi sebagai dasar pengambilan keputusan; (e) memantau penerapan keputusan; dan (f) memperkuat relasi yang positif dengan pemerintah atau amsyarakat setempat.

Kepemimpinan fasilitatif dengan indikasi: (a) mengusahakan dan menyediakan sumber-sumber yang diperlukan; (b) menetapkan dan memperkuat kembali kebijakan organisasi; (c) menekan atau memperkecil kertas kerja yang birokratis; (d) memberikan saran atas masalah kerja yang birokratis; (e) membuat jadwal kegiatan; dan (f) membantu pekerjaan agar dilaksanakan.

Kepemimpinan suportif yang mencakup: (a) memberikan dorongan dan penghargaan atas usaha orang lain; (b) menunjukkan keramahan dan kemampuan untuk melakukan pendekatan; (c) mempercayai orang lain dengan pendelegasian tanggung jawab; (d) memberikan ganjaran atas usaha perseorangan; dan (e) meningkatkan moral/semangat staf.

Kepemimpinan partisipatif ialah perilaku kepemimpinan yang menunjukkan tanda-tanda : (a) pendekatan akan berbagai persoalan dengan pikirab terbuka; (b) mau atau bersedia memperbaiki posisi-posisi yang telah terbentuk; (c) mencari masukan dan nasihat yang menentukan; (d) membantu perkembangan kepemimpinan yang posisional dan kepemimpinan yang sedang tumbuh; (e) bekerja secara aktif dengan perseorangan atau kelompok; dan (f) melibatkan orang lain secara tepat dalam pengambilan keputusan.

Keberhasilan atau kegagalan pemimpin ditentukan oleh gaya bersikap dan bertindak seorang pemimpin yang bersangkutan. Menurut Sutarto (Sutrisno, 2009:242) bahwa "Gaya bersikap dan bertindak seorang pemimpin akan tampak dari cara : (1) memberi perintah; (2) memberikan tugas; (3) berkomunikasi; (4) membuat keputusan; (5) mendorong semangat bawahan; (6) memberikan bimbingan; (7) menegakkan disiplin; (8) mengawasi pekerjaan bawahan; (9) meminta laporan dan bawahan; (10) 


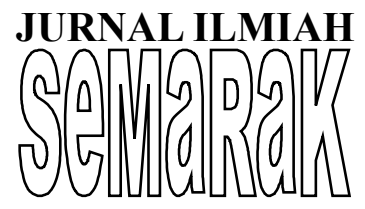

memimpin rapat; dan (11) menegur kesalahn bawahan".

Sejumlah ahli teori kepemimpinan menekankan style dari pemimpin yang efektif, yaitu berkisar pada kepemimpinan dengan gaya partisipatif, non-partisipatif, otokratik, demokratik, atau laissez-faire. Kunci penting dari gaya kepemimpinan ini dalam satuan pendidikan adalah memahami kebutuhan-kebutuhan dan keinginan-keinginan setiap persoalan ini adalah memenuhi strategi pencapaian target dan tujuan organisasi. Sejalan dengan pendapat tersebut ada tiga gaya kepemimpinan yang diperagakan oleh Woods dalam Sagala, (2006:159-151), yaitu: "(1) otokratis (pemimpin yang membuat keputusan sendiri); demokratis atau partisipatif (pemimpin mengambil keputusan secara bersamasama); dan (3) kendali bebas (bebas memberi kekuasaan penuh kepada bawahan".

Menurut Herabudin (2009:190-191) menggambarkan ada lima gaya kepemimpinan, sebagai berikut: “(1) pemimpin otokratis adalah pemimpin yang memiliki wewenang penuh; (2) birokratis adalah pemimpin yang mengatur bawahannya dengan berpegang pada aturan-aturan yang telah ditetapkan; (3) diplomatis adalah pemimpin cenderung menjual sesuatu (memotivasi) kepada bawahannya; (4) pemimpin partisipatif yang sentiasa mengundang terbuka kepada orang bawahan untuk mengambil bahagian atau mengambil bahagian; dan (5) pemimpin menguasai bebas adalah pemimpin yang meninggalkan bawahannya tanpa pengawasan sama sekali .

Gaya kepimpinan adalah corak tingkah laku kepimpinan untuk mempengaruhi, menggalakkan, membimbing, mengarahkan, dan memindahkan pekerja untuk melakukan apa yang mereka mahu untuk mencapai matlamat yang ditetapkan. Gaya kepimpinan dapat diukur dengan dimensi berikut: (1) autokratik, (2) birokratik, (3) diplomatik, (4) partisipatif, (5) pemimpin menguasai bebas.

\section{Kinerja Karyawan (Y)}

Pengertian kinerja memiliki arti yang luas, menurut Rivai (2009:548), menyatakan bahwa "Kinerja merupakan perilaku nyata yang ditampilkan setiap orang sebagai prestasi kerja yang dihasilkan oleh pegawai sesuai dengan perannya dalam organisasi”. Prestasi adalah fungsi motivasi dan keupayaan untuk menyelesaikan tugas seseorang atau bekerja dengan sewajarnya mempunyai tahap keinginan dan kemampuan tertentu.

Menuurut Sutrisno (2009:165), bahwa "Prestasi kerja (kinerja) adalah sebagai hasil kerja yang telah dicapai oleh seseorang dari tingkah laku kerja dalam 
melaksanakan kegiatan kerja ". Prestasi lebih cenderung untuk memberikan makna pencapaian sebagai "hasil" atau "apa yang keluar" (hasil) pekerjaan kepada prestasi seseorang yang telah mencapai. Prestasi seseorang dapat dilihat melalui keikhlasannya dalam menjalankan tugas dan tanggungjawabnya sesuai dengan pekerjaan yang diberikan kepadanya.

Menurut Sagala menyatakan "Prestasi adalah manifestasi kerja yang dicapai oleh institusi. Ukuran kejayaan sesebuah institusi termasuk semua aktiviti setelah melalui ketekunan wajar terhadap perniagaan yang telah ditentukan dan dilaksanakan ". Piawaian prestasi kerja (piawai prestasi) menetapkan tahap prestasi kerja yang diharapkan dari pelaksanaan dan kriteria untuk mengukur kejayaan kerja. Piawaian prestasi kerja selalunya pernyataan mengenai prestasi yang boleh dicapai untuk pekerjaan tertentu.

Simamo (2006:115-116) menjelaskan "Beberapa persyaratan yang harus dipenuhi standar kinerja pekerjaan adalah : (1) relevan dengan individu dan organisasi; (2) stabil dan andal; (3) dapat membedakan antara pelaksanaan pekerjaan baik, sedang, atau buruk; (4) dapat dijabarkan dalam angka; (5) mudah diukur; (6) mudah dipahami; dan memberikan interprestasi yang tidak bias".
Menurut Maier Notoatmodjo (2009:124) mendefinisikan "Kinerja adalah "Kesuksesan seseorang dalam melaksanakan suatu pekerjaan yang diembannya". Kinerja merupakan hasil kerja yang dapat ditampilkan atau penampilan kerja seseorang pegawai. Dengan demikian kinerja seseorang pegawai dapat diukur dari hasil kerjanya, hasil tugasnya, atau hasil kegiatan dalam kurun waktu tertentu. Pengertian kinerja dapat diartikan sebagai hasil prestasi kerja yang ditampilkan dan dilakukan seseorang sesuai dengan perannya dalam suatu organisasi tempatnya bekerja.

Menurut Notoatmojo (2009:133), daalam kehidupan suaatu orgaanisasi ada beberapa asumsi tentang perilaku manusia sebagai SDM yang mendasari pentingnya penilaian prestasi kerja, antara lain “(1) setiap orang ingin memiliki peluang untuk mengembangkan kemampuan kerjanya (prestasinya) sampai tingkat maksimal; (2) setiap orang ingin mendapat penghargaan, apabila ia dinilai mampu melaksanakan tugas dengan baik; (3) setiap orang ingin mengetahui secara pasti tangga karier yang dilewatinya; (4) setiap orang ini mendapatkan perlakuan yang obyektif dan penilaian atas dasar prestasi kerjanya; (5) setiap orang bersedia menerima tanggung jawab yang lebih besar; dan (6) setiap 


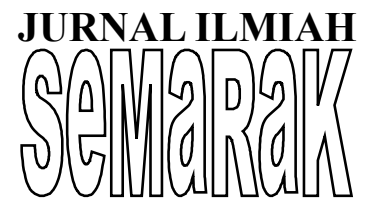

orang ingin mengetahui hasil kerja tersebut, atau umpan balik".

Menurut Dessler

(2006:322)

menyatakan bahwa penilaian kinerja berarti mengevaluasi kinerja seseorang saat ini dan atau dimasa lalu relatif terhadap standar kinerjanya. Saat penilaian kinerja biasanya terlintas alat penilaian terhadap standar kinerjanya". Penilaian kinerja juga mengamsusikan behwa seseorang dapat memehami apa standar kinerjanya dan memberikan umpan balik, pengembangan, dan insentif yang diperlukan untuk membantu orang yang bersangkutan menghilangkan kinerja merupakan salah satu faktor yang memegang peranan penting dalam keberhasilan instansinya. Pegawai merupakan faktor sentral dalam pendidikan nasional. Pembangunan pendidikan secara umum ditekankan pada usaha untuk meningkatkan mutu pendidikan. Salah satu faktor utama yang sangat menentukan dalam meningkatkan mutu pendidikan adalah keefektifan kerja pegawainya. Mutu pendidikan akan meningkat bila didukung oleh keefektifan kerja pegawainya. Kinerja pegawai akan baik apabila pegawai tersebut memiliki kompetensi yang tinggi.

Menurut Simamora (2006:117) menyatakam bahwa "Tujuan pembuatan standar kinerja pekerjaan untuk mrmbrntuk pedoman pengukuran kinerja aktual. Hal ini berfaedah bagi orang yang menduduki jabatan dan atasan yang mengevaluasi kinerja orang yang bersangkutan". Semakin seseorang tersebut sanggup mengemban tanggung jawab posisi tersebut kemungkinan bahwa orang tersebut secara mulus. Pada akhirnya, penilaian kinerja dapat lebih objektif dan relevan sesuai dengan yang diharapkan. Hal demikian menjadi upaya dalam mengantisipasi kinerja yang buruk secara khusus pemimpin perlu mencarikan solusi untuk meningkatkan kinerja pegawai yang dipimpinnya.

Rivai (2009:547) menyatakan bahwa "Kinerja dipengaruhi oleh bermacammacam ciri pribadi dari masing-masing individu, oleh karena itu, penilaian prestasi kerja seharusnya menggambarkan kinerjanya". Pengaruh faktor-faktor seperti tipe pekerjaan, rasa aman, kondisi tempat kerja dan teman kerja akan berbeda bagi orang yanf satu dengan yang lainnya. Perbedaan ini disebabkan oleh adanyan perbedaan kepribadian yang dimiliki oleh masing-masing orang tersebut, serta kebutuhan akan hidupnya.

Banyak faktor yang dapat mempengaruhi kinerja seseorang, namun faktor yang paling dominan dapat mempengaruhi pencapaian kinerja menurut Mangkunegara (2008:67) adalah 


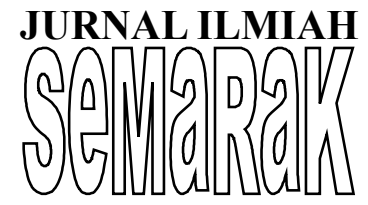

"Faktor ability (kemampuan) dan faktor motivation (motivasi)". Secara psikologis, kemampuan pegawai terditi dari kemampuan potensi (IQ) dan kemampuan reality (knolage skill). Artinya pegawai yang memiliki IQ di atas rata-rata (IQ 110120) dengan pendidikan yang memadai untuk jabatannya dan terampil dalam mengerjakan pekerjaannya, maka ia akan mudah mencapai kinerja yang diharapkan.

Byar dan Rue (Sutrisno, 2009:165) menyatakan bahwa "Ada dua faktor yang mempengaruhi kinerja, yaitu faktor individu dan lingkungan". Faktor-faktor individu meliputi usaha (effort), sifat personal (abilities), dan perilaku/aktivitas (role/task perception). Sedangkan faktor lingkungan meliputi kondisi fisik, peralatan, waktu, material, pendidikan, supervisi, desain organisasi, pelatihan dan keberuntungan. Walaupun setiap faktor secara sendiri-sendiri dapat juga mempunyai arti yang penting, tetapi kombinasi kedua faktor tersebut sangat menentukan tingkat hasil setiap pekerjaan, yang pada gilirannya membantu prestasi organisasi secara keseluruhan.

Andrew E. Sekula (Mangkunegara, 2008:69) menyatakan bahwa "Penilaian pegawai merupakan evaluasi yang sistematis dari pekerjaan pegawai dan potensi yang dapat dikembangkan”. Penilaian merupakan proses penaksiran atau penentuan nilai, kualitas, atau status dari beberapa obyek, orang ataupun sesuatu.

Anderson (Irianto, 2001:61) menyatakan bahwa "Untuk mengukur variabel kinerja mangacu kepada komponen-komponen yang ada dalam kinerja, yaitu : performer (unjuk kerja meliputi prakarsa dan kerja sama), behaves (perilaku meliputi kesetiaan, tamggung jawab, ketaatan, dan kejujuran), dan to achieve result (pencapaian hasil kerja)".

Menurut Surtisno (2009:167) menyatakan bahwa "Untuk mengukur kinerja kerja pegawai diarahkan pada enam aspek yang merupakan bidang prestasi kunci bagi instansi, yaitu : hasil kerja, pengetahuan pekerjaan, inisiatif, kecekatan mental, sikap, dan disiplin.

Rucker (Irianto, 2001:61) menyatakan bahwa "Tujuan yang hendak dicapai sedapat mungkin spesifik dan dapat diukur, menantang pekerjaan dan dapat dicapai”. Efektivitas penetapan tujuan tergantung pada seberapa besar tingkat partisipasi pekerja dalam upaya menetapkan tujuan. Keterlibatab ini mengidentifikasikan bahwa tujuan yang ditetapkan baersama akan mengarahkan pada komitmen pekerja untuk ikut bertanggung jawab mencapai tujuan yang telah disetujui bersama.

\section{E. Hipotesis Penelitian}




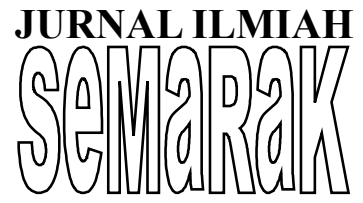

Hipotesis yang diuji dalam penelitian ini berkaitan dengan ada atau tidaknya pengaruh yang signifikan dari seperangkat variabel bebas (independent variable) terhadap variabel terikat (dependent variable). Adapan hipotesis yang diuji yakni sebagai berikut:

$\mathrm{H}_{\mathrm{o}} \quad$ : variabel gaya kepemimpinan tidak berpengaruh terhadap kinerja karyawan.

$\mathrm{H}_{\mathrm{a}}$ : variabel gaya kepemimpinan berpengaruh terhadap kinerja karyawan.

\section{METODE PENELITIAN}

Penelitian dilakukan pada SMA Islam Al-Azhar BSD. Metode yang digunakan dalam penelitian ini adalah menggunakan metode kuantitatif asosiatif, menurut Sugiyono (2014:35) “ Metode kuantitatif dapat diartikan sebagai metode penelitian yang berlandaskan pada filsafat positivisme, digunakan untuk meneliti pada populasi atau sampel tertentu, pengumpulan data menggunakan instrumen penelitian, analisis data bersifat kuantitatif/statistik, dengan tujuan untuk menguji hipotesis yang telah ditetapkan". Dengan menggunakan metode analisis regresi linier sederhana. Mengingat responden atau populasi yang menjadi objek penelitian ini di bawah 100 orang, maka penulis mengambil keseluruhan pegawai yaitu 46 orang responden yang ditetapkan sebagai sampel jenuh. karyawan di SMA Islam Al-Azhar Bumi Serpong Damai Tangerang Selatan, yang berjumlah 46 orang.

Pengumpulan data dilakukan dengan cara dokumentasi, wawancara dan kuesioner.

\section{HASIL DAN PEMBAHASAN}

\section{A. Gambaran Objek Penelitian}

Untuk menyumbang kepada kehidupan intelektual negara sebagaimana yang dimandatkan dalam Pembukaan Undang-Undang Dasar 1945. Lembaga Pengasas Yayasan Muslim Serat Bumi Bumi telah mengambil inisiatif untuk mendirikan Universitas Islam Al Azhar Bumi Serpong Damai yang tercermin dalam Akta Notaris Pembangunan Fisik Tadika, Elementary, Sekolah Menengah Pertama dan Sekolah Tinggi Al Azhar Yayasan Bumi Serpong Damai dan Masjid Asy Syarif adalah manifestasi konkrit untuk usaha ini.

Pelaksanaan pendidikan di Sekolah Islam Al Azhar Bumi Serpong Damai diarahkan pada pembentukan golongan muda yang berpengetahuan, berpengetahuan, mempunyai kepribadian tinggi dan mentalitas mental. Untuk tujuan ini, secara teknikal pada awal pentadbiran sekolah, Yayasan Muslim Bumi Serpong Damai bekerjasama dengan Pengurus Yayasan Syifa Budi Al Azhar Sekolah Islam Kemang di Jakarta, Ketua Tn. H. Maulwi Saelan.

Pada 23 Jun 1992 di Jakarta Horizon Hotel, dua asas menandatangani surat 


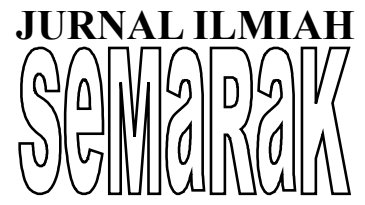

perjanjian dan pemahaman kerjasama antara Yayayasan Muslim Bumi Serpong Damai dan Yayasan Syifa Budi. Memandangkan pelantikan H. Subagdja Prawata dari Yayasan Muslim Bumi Bumi Serpong Damai dan H. Maulwi Saelan dari Yayasan Syifa Budi. Turut hadir pada majlis itu ialah Ir. Budiarsa Presiden Pengarah PT. Bumi Serpong Damai, Hj. Ida Saodah Dawam Al Azhar Kemang Penguasa Sekolah Kemang, SD Al Azhar Bumi Serpong Damai.

Dengan semangat dan sokongan dari Lembaga Pengasas Yayasan Muslim Serpong Damai dan PT. Bumi Serpong Damai di bawah bimbingan Al Azhar Kemang pada 20 Juli 1992 merasmikan pembukaan Sekolah Taman Kakak-Sis dan Sekolah Dasar Islam Al Azhar Bumi Serpong Damai Filial Al Azhar Kemang Jakarta.

Sekolah Tinggi Al Azhar Bumi Serpong Damai kini dikenali sebagai Sekolah Al-Islam Al Azhar Bumi Serpong Damai untuk pendaftaran kali pertama dan kemasukan pelajar baru bermula pada tahun akademik 1996/1997. pelaksanaan pendidikan dasar berdasarkan keputusan Kantor Wilayah Kementerian Pendidikan dan Kebudayaan Provinsi Jawa Barat Nomor. 34 / I02.1 / Kep / OT / 1998. Pada masa ini, pada awal pembukaan, semua aktiviti pembelajaran menggunakan bangunan bersama dengan unit Sekolah Menengah Islam Al Azhar Bumi Serpong Damai.

Dengan pembukaan Sekolah Islam Al Azhar Bumi Serpong Damai, Yayasan
Muslim Bumi Bumi Serpong juga menganjurkan pendidikan bermula dari pra sekolah, pendidikan asas dan pendidikan menengah. Sebagai Pengetua Yayasan Muslim Bumi Bumi Serpong Damai yang dilantik sebagai Aslim Munik BE, hingga akhir tahun 1997/1998 dan digantikan oleh Drs. Kamaludin Makmun, Sm.Q, bermula pada tahun 1998/1999 hingga tahun 2002/2003.

Sekolah Menengah Islam Al Azhar Bumi Serpong Damai ditubuhkan oleh Yayasan Muslim Bumi Bumi Serpong Damai dengan Surat Keputusan: SK-05 / YMBSD / VI / 1996, bertarikh 1 Juli 1996; terletak di Puspita Loka Sektor 3.2 Bumi Serpong Damai, Kabupaten Serpong Kabupaten Tangerang, Provinsi Banten. Menduduki sebuah bangunan yang dimiliki oleh Yayasan Muslim Bumi Bumi Serpong Damai. Lesen operasi Sekolah Menengah Islam Al Azhar Bumi Serpong Damai dikeluarkan melalui Keputusan Kepala Kantor Wilayah Departemen Pendidikan dan Kebudayaan Jawa Barat, Nomor: 34 / 102.1 / Kep / OT / 1998, 15 Januari 1998. Pada Tahun Akademik 2000/2001 Sekolah Tinggi Islam Al Azhar BSD telah diakreditasi, dan status sekolah adalah BAMED mengikut Keputusan No. Kannas Diknas Jawa Barat No. 27 / $102.7 \mathrm{~g} / \mathrm{MN} / 2000$ bertarikh 26 Januari 2000. dan kemudian telah diakreditasi lagi dan telah diakreditasi ulang oleh Badan Akreditasi Sekolah-BASDA Keputusan Badan Akreditasi Sekolah Provinsi Banten: 02 / BAS / MN / IV / 2005,18 April 2005 dengan nilai ACCREDITED A 


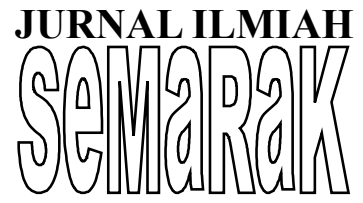

\section{B. Analisis dan Pembahasan}

1. Hasil Uji Valiiditas

Ujian kesahan digunakan untuk menguji soalan atau pernyataan soal selidik yang diedarkan sah atau tidak. Pengiraan adalah dengan membandingkan tcount dengan ttable dengan tahap signifikansi 5\% (ralat). Jika tcount lebih besar daripada jadual nilai maka soalan item dikatakan sah. Untuk menentukan data yang diperoleh dari hasil penyelidikan boleh digunakan atau tidak, penulis menggunakan ujian kesahihan .

Berdasarkan hasil pembolehubah gaya kepemimpinan, dapat dilihat bahwa nilai keseluruhan Koefisien korelasi tcount mempunyai nilai lebih besar daripada ttable atau tcount lebih besar dari 1.68. Oleh itu, dapat disimpulkan bahawa 15 item pernyataan adalah sah. Perkara yang mempunyai kesahan tertinggi adalah item keempat belas dalam jumlah 8.55 dan item terendah ialah 3,6,11, dan 12 dalam jumlah 5.24 .

Berdasarkan hasil pemboleh ubah prestasi pekerja, dapat dilihat bahwa nilai keseluruhan Koefisien korelasi tcount mempunyai nilai lebih besar dari ttable atau tcount lebih besar dari 1.68. Oleh itu, dapat disimpulkan bahawa 15 item pernyataan adalah sah. Item yang mempunyai kesahan tertinggi ialah item kedua iaitu 6.88 dan item terendah ialah item kesembilan iaitu 5.24 .

\section{Hasil Uji Reliabilitas}

Berdasarkan hasil uji kebolehpercayaan dalam gaya kepimpinan varriabel, dapat dilihat bahwa (Dapat diandalkan karena nilai hitung $r$ lebih besar dari rtabel momen produk, 0.89> $0.285)$.

Berdasarkan hasil uji kebolehpercayaan pada pemboleh ubah prestasi pekerja, nampaknya (Dipercayai kerana nilai penghitungan $r$ lebih besar dari momen produk rtabel adalah 0.66> $0.285)$

3. Pengaruh Gaya Kemimpinan Terhadap Kinerja SMA Al Azhar BSD

Berdasarkan pengiraan di atas, hasil $r$ adalah 0.68. ini menunjukkan bahawa antara Gaya Kepimpinan dan Prestasi Pekerja di Sekolah Tinggi Al-Azhar Bumi Serpong Damai terdapat pengaruh yang kuat. Ini bermakna Gaya Kepimpinan akan sangat mempengaruhi Prestasi Pekerja di Sekolah Tinggi Islam Islam Serpong Damai Al-Azhar.

\section{Hasil Koeffisien Deteerminasi $\left(R^{2}\right)$}

Untuk mengetahui berapa varians pembolehubah Y ditentukan oleh pemboleh ubah X, pekali ujian penentuan digunakan dengan menggunakan formula berikut :

$$
\begin{aligned}
\mathrm{Kd} & =r^{2} \times 100 \% \\
& =(0,68)^{2} \times 100 \% \\
& =0,4624 \times 100 \% \\
& =46,24 \%
\end{aligned}
$$

Koefisiensi determinasi sebesar $46,24 \%$ ini menunjukkan bahawa tahap Kepimpinan Gaya Pengaruh ke atas 


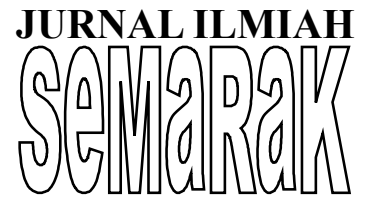

Prestasi Pekerja sebanyak 46.24\% sementara baki $53.76 \%$ adalah pengaruh lain.

\section{Hasil Uji Hipotesis}

Selanjutnya untuk mengetahui apakah gaya kepemimpinan memiliki keberartian dalam meningkatkan kinerja perlu dilakukan uji signifikansi korelasi dengan menggunakan uji-t sebagai berikut:

Hipotesis :

Ho : Koefisien korelasi tidak signifikan

Ha : Koefisien korelasi signifikan

Ketentuan : Terima $\mathrm{H}_{\mathrm{o}}$, Jika $\mathrm{t}_{\text {hitung }}<\mathrm{t}_{\text {table }}$

Tolak $\mathrm{H}_{\mathrm{o}}$, Jika $\mathrm{t}_{\text {hitung }} \geq \mathrm{t}_{\text {table }}$

Berdasarkan hasil perhitungan dari penelitian tersebut di atas maka dapat diberikan uji hipotesis sebagai berikut :

Tolaak $\mathrm{H}$ o attau teerima $\mathrm{H}$ a, karena $\mathrm{t}$ hitung $>\mathrm{t}$ table, berarti bahwa koefisien korrelasi antaara X dan Y siignifikan. Data tersebut menunjukkan bahwa gaya kepemimpinan pada SMA Islam Al Azhar Bumi Serpong Damai berpengaruh terhadap kinerja, hal ini dapat dilihat dari besarnya nilai $r$ sebesar 0,68 yang menunjukkan pengaruh antara $\mathrm{X}$ dan $\mathrm{Y}$ adalah kuat

\section{KESIMPULAN DAN SARAN}

\section{A. Kesimpulan}

Dari hasil peneliitian terhadap karyawan Sekolah Al-Azhar Bumi Serpong Damai dengan menggunakan analisa secara korelasi product moment makaa daapat diitarik keesimpulan seebagai beerikut :

1. Gaya Kepemimpinan yang diterapkan oleh pimpinan Sekolah Al-Azhar adalah kuat. Hal ini terlihat dari responden atau tanggapan responden yang menyatakan setuju dan sangat setuju atas pertanyaanpertanyaan yang di dalamnya mencerminkan dari berbagai jenis gaya kepemimpinan, adapun besarnya sebesar $72,46 \% \quad(\mathrm{SS}+\mathrm{S}=22,46 \%+50 \%$ $=72,46 \%$ ), sisanya $27,54 \%$ disebabkan oleh faktor lain.

2. Dari hasil perhitungan diatas dapat disimpulkan kinerja karyawan di Sekolah Al-Azhar adalah kuat. Hal ini terlihat dari responden atau tanggapan responden yang menyatakan sangat setuju daan setuju atas pertanyaan-pertanyaan yang di dalamnya mencerminkan dari kinerja karyawan, adapun besarnya sebesar $75,22 \%$ ( SS ; $25,65 \%+\mathrm{S} ; 49,57 \%=75,22 \%)$, sisanya $24,78 \%$ disebabkan oleh faktor lain.

Pengaruh gaya kepemimpinan terhadap kinerja karyawan di Sekolah Al-Azhar dapat dilihat dari besarnya nilai rxy sebesar 0,68 yanng mennunjukkan penggaruh vaariabel $\mathrm{X}$ terhhadap variiabel $\mathrm{Y}$ adalah kuat. Uji signifikansi dengan uji $\mathrm{t}$ adalah $\mathrm{t}$ hitung $>\mathrm{t}$ tabel atau 6,18>1,68. Artinya dari hasil penghitungan terhadap uji secara simultan menunjukan bahwa terdapat peengaruh yang siggnifikan dari gayya kepeemimpinan terrhadap kiinerja karyaawan SMA Islam Al-Azhar.

\section{B. Saran}




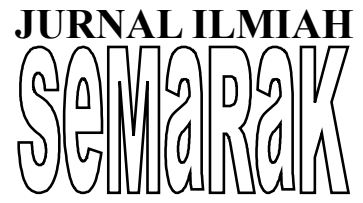

Penelitian ini memberikan sumbangsih saran bagi kemajuan Sekolah Al-Azhar terutama dibidang sumber daya manusia mengenai gaya kepemimpinan dengan saran-saran dalam peningkatan kinerja karyawan. Saran masukan dari peneliti untuk Sekolah Al-Azhar adalah:

1. Kepala sekolah agar lebih mengontrol guru dan karyawan dalam menjalankan tugas nya serta mampu memotivasi karyawan dengan menjanjikan imbalan kepada karyawan apabila mampu melaksanakan pekerjaanya dengan adanya bonus di akhir tahun dari yayasan serta lebih memperhatikan kerja kelompok daripada kompetensi individu.

2. Pegawai (guru dan karyawan) mengerjakan pekerjaan atau aktivitas tanpa rasa takut tetapi bisa membuat suasana nyaman serta memahami kalau aktivitas yang dilakukan ada kaitannya dengan tujuan kelompok yang akan dicapai.

\section{DAFTAR PUSTAKA}

Ardana, I Komang, Mujiati, Ni Wayan \& Utama, I Wayan Mudhiartha, "Sumber Daya Manusia", Graha Ilmu, Yogyakarta, 2012 .

Ayudiarini, Natassia, "Pengaruh Iklim Organisasi Dan Pengembangan Karir Terhadap Kepuasan Kerja", Jurnal Gunadarma, Depok, 2010 .

Bhuono, Agung, "Strategi Jitu Memilih Metode Statistik dengan Perangkat Lunak". Andi, Yogyakarta, 2005 .
Chaisunah dan dan Muttaqiyathun, "Pengaruh Kompensasi Dan Lingkungan Kerja Terhadap Kepuasan Kerja Karyawan (Studi Kasus Pada BPR Shinta Daya)", Universitas Ahmad Dahlan, Jakarta, 2011

Djarwadi, "Pengaruh Lingkungan Organisasi Terhadap Kepuasan Kerja di BPPT", Jurnal Manajemen Sumber Daya Manusia, Jakarta, 2011.

Faozi, Muhammad, "Pengaruh Komitmen Organisasi, Kompensasi, Budaya Kerja, Motivasi Dan Iklim Organisasi Terhadap Kepuasan Kerja (Studi Kasus Pada Guru SMP Negeri Dan Swasta Di Kecamatan Tarub Kabupaten Tegal)”, Jurnal Magister Manajemen Udinus Semarang, Edisi Juli 2014, Semarang, 2014 .

Ghozali, Imam, “Aplikasi Analisis Multivariat Dengan Program SPSS 19”, Badan Penerbit Universitas Dipenogoro, Semarang, 2011 .

Griffin, Ricky W dan Ronald J. Ebert, "Bisnis Edisi Kedelapan, Erlangga, Jakarta, 2007 .

Hasibuan, Melayu, "Manajemen Sumber Daya Manusia”, PT. Bumi Aksara, Jakarta, 2012 .

http://www.tribun-

maluku.com/2015/01/hadapi-aec2015, sdm.html, diakses pada tanggal 17 September 2015.

Koesmono, Teman, "Pengaruh Budaya Organisasi Terhadap Motivasi Dan Kepuasan Kerja Serta Kinerja Karyawan Pada Sub Sektor Industri Pengolahan Kayu Skala Menengah Di Jawa Timur", Jurnal Manajemen, Surabaya, 2005 .

Kurniawan, Agung, "Transformasi Pelayanan Publik", Pembaruan, Yogyakarta, 2005 . 
Lestari Anjani dan Hutami Rieke Febriyanti, "Pengaruh Budaya Organisasi Terhadap Kepuasan Kerja Karyawan Telkom Foundation (TF), Jurnal Manjemen, Bandung, 2014.

Mangkunegara, Anwar Prabu, "Sumber Daya Manusia perusahaan", Remaja Rosdakarya, Bandung, 2005.

Melinda, Kamaludin dan Nasution "Analisis Pengaruh Iklim Organisasi Dan Promosi Jabatan Terhadap Kepuasan Kerja Karyawan PT. Bank Bengkulu Cabang Utama", Jurnal Ilmiah Manajemen, Volume 13, Nomor 1, April 2013, Bengkulu, 2013.

Moeljono, Djokosantoso, "Budaya Organisasi dalam tantangan”, PT. Elex Media Komputindo, Jakarta, 2005.

Muchlas, Makmuri, "Perilaku Organisasi", Gadjah Mada University Press, Yogyakarta, 2005.

Munandar, Ashar Sunyoto, "Psikologi industri dan organisasi", Depok. Universitas Indonesia, 2010.

Notoatmodjo, Soekidjo, "Pengembangan Sumber Daya Manusia", Rineka Cipta, Jakarta, 2009.

Reflita, Isyandi dan Yulia Efni, "Pengaruh Iklim Organisasi Dan Remunerasi Terhadap Motivasi Dan Kepuasan Kerja Paramedis Di Rumah Sakit Umum Puri Husada Tembilahan Kabupaten Indragiri Hilir", Jurnal Tepak Manajemen Bisnis, Vol. VI No. 1 Januari 2014, Riau, 2014.

Rivai, Veithzal, "Manajemen Sumber Daya Manusia untuk Perusahaan", Edisi Kedua, Rajawali Pers, Jakarta, 2009.

Robbins, Stephen P, "Perilaku Organisasi”, Edisi kesepuluh, PT. Indeks Kelompok Gramedia, Jakarta, 2006.
Rosidah, Ambar Teguh Sulistiyani, "Manajemen Sumber Daya Manusia", Graha Ilmu, Yogyakarta, 2009.

Subhki, Akhmad, Muhammad Jauhar,"Pengantar Teori dan perilaku organisasi", Prestasi Pustaka Publisher, Jakarta, 2013.

Sugiyono, "Metode Penelitian Bisnis", Edisi V, CV IKAPI, Bandung, 2010.

Suharyadi, Purwanto S.K, "Statistik :Untuk Ekonomi Dan Keuangan Modern”, Edisi 2, Salemba Empat, Jakarta, 2009.

Pasaribu, V. L. D., \& Krisnaldy, K. (2018). ANALISIS KEPUASAN JAMA'AH PADA KINERJA DEWAN KEMAKMURAN MASJID AL-HIDAYAH PERIODE TAHUN 2017. KREATIF: Jurnal Ilmiah Prodi Manajemen Universitas Pamulang, 6(4), 41-51. 